\title{
Indole alkaloid from the Red Sea sponge Hyrtios erectus
}

\author{
Mohamed A. Ashour, ${ }^{a}$ Ehab S. Elkhayat, ${ }^{b *}$ Rainer Ebel, ${ }^{c}$ RuAngelie Edrada, \\ and Peter Proksch ${ }^{\mathrm{c}}$ \\ ${ }^{a}$ Faculty of Pharmacy, Al-Azhar University, Pharamcognosy Department, Cairo, Egypt \\ ${ }^{b}$ Faculty of Pharmacy, Al-Azhar University, Pharamcognosy Department, Assiut 71524, Egypt \\ ${ }^{c}$ Institut für Pharmazeutische Biologie, Heinrich-Heine-Universität, Universitätsstr 1, 40225 \\ Düsseldorf, Germany \\ E-mail: Khayat71@yahoo.com
}

\begin{abstract}
Indole-3-carbaldehyde and 5-deoxyhyrtiosine A are reporterd for the first time in the genus Hertios, in addition to other indole alkaloids and three scalarane sesterterpenes, from the Red Sea sponge Hertios erectus. The isolated compounds were tested for their cytotoxic and antimicrobial activities.
\end{abstract}

Keywords: Hertios erectus, indole alkaloids, indole 3- carbaldehyde, 5-deoxyhyrtiosine A

\section{Introduction}

The secondary metabolites from the genus Hyrtios particularly Hertios erectus (synonym $H$. erecta) have been investigated extensively ${ }^{1-5}$. Previous chemical investigations of different Hyrtios sp. and their associated microorganisms revealed the presence of numerous structurally unique natural products including scalarane sesterterpenes, acyclic triterpenes, indole alkaloids, and macrolides in addition to steroids. Many of these compounds possess interesting biological activities. Spongistatins, the most important metabolites of the genus Hyrtios discovered to date, showed powerful anticancer activity ${ }^{6,7}$, which encouraged an exhaustive recollection of the $H$. erecta sponge (600 kg wet wt.) for further chemical investigations, which afforded the antineoplastic agents sesterstatins ${ }^{8-10}$.

In the present study, $H$. erectus collected from the Red Sea - Egypt was chemically investigated and a series of indole alkaloids were isolated, deoxyhyrtiosine A (1) and indole-3carbaldehyde (2) isolated for the first time from the genus Hyrtios; in addition to the known indoles; 5-hydroxy-1H-indole-3-carboxylic acid methyl ester (3), 5-hydroxy-1H-indole-3carbaldehyde (4) and hyrtiosine A (5) were obtained. Three scalarane sesterterpenes: 16hydroxyscalarolide (6), scalarolide (7) and 12-O-deacetyl-12-epi-scalarine (8), besides $5 \alpha, 8 \alpha$ - 
epidioxy-cholesta-6-en-3 $\beta$-ol (9) were also isolated. The structures of the isolated compounds were elucidated using 1D and 2D-NMR spectroscopy and and mass spectrometry.

5-Hydroxy-1H-indole-3-carboxylic acid methyl ester, indole-3-carbaldehyde and 16hydroxyscalarolide showed growth inhibition activity against the L5178Y cell line. Deoxyhyrtiosine, 5-hydroxy indole-3-carbaldehyde and 16-hydroxyscalarolide showed mild antimicrobial activities against Bacillus subtilis and Saccharomyces cerevisiae.

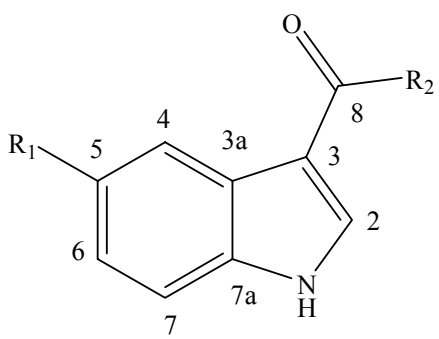

$$
\begin{array}{ll}
\text { 1: } \mathrm{R}_{1}=\mathrm{H} & \mathrm{R}_{2}=\mathrm{CH}_{2} \mathrm{OH} \\
\text { 2: } \mathrm{R}_{1}=\mathrm{H} & \mathrm{R}_{2}=\mathrm{H} \\
\text { 3: } \mathrm{R}_{1}=\mathrm{OH} & \mathrm{R}_{2}=\mathrm{OCH}_{3} \\
\text { 4: } \mathrm{R}_{1}=\mathrm{OH} & \mathrm{R}_{2}=\mathrm{H} \\
\text { 5: } \mathrm{R}_{1}=\mathrm{OH} & \mathrm{R}_{2}=\mathrm{CH}_{2} \mathrm{OH}
\end{array}
$$

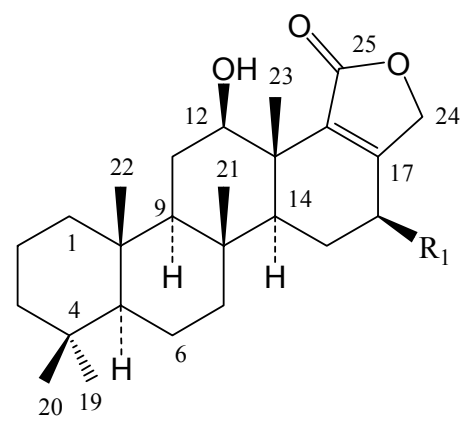

$$
\begin{aligned}
& \text { 6: } \mathrm{R}_{1}=\mathrm{OH} \\
& \text { 7: } \mathrm{R}_{2}=\mathrm{H}
\end{aligned}
$$
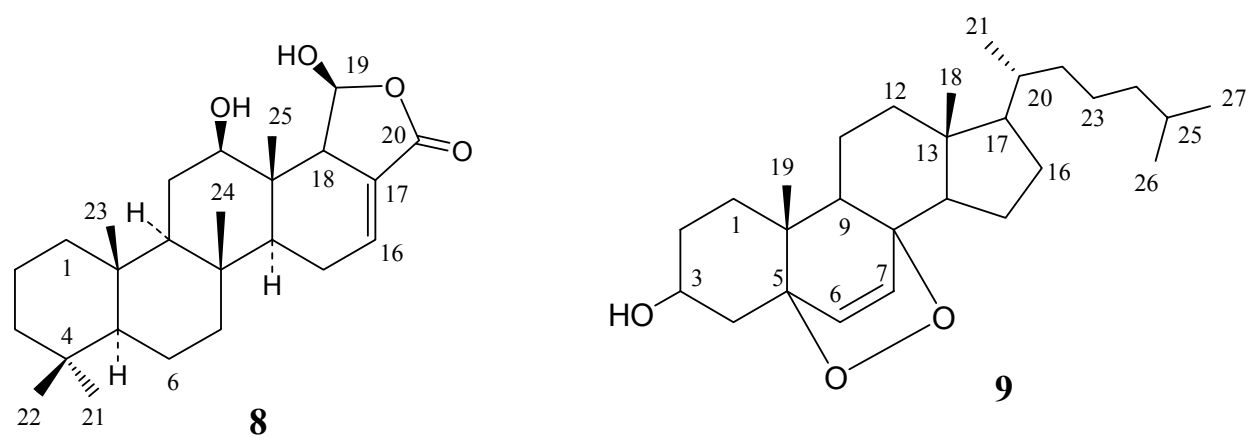

Figure 1. Structure of the isolated compounds.

\section{Results and Discussion}

The $\mathrm{CH}_{2} \mathrm{Cl}_{2}$-soluble residue of the alcoholic extract of the red sea sponge $H$. erectus was subjected to vacuum-liquid chromatography eluting with $\mathrm{CH}_{2} \mathrm{Cl}_{2}-\mathrm{MeOH}$ followed by silica gel column chromatography to afford four compounds (6-9). While the $\mathrm{MeOH}$-soluble residue was subjected to vacuum-liquid chromatography eluting with gradient $\mathrm{CH}_{2} \mathrm{Cl}_{2}-\mathrm{MeOH}$ followed by silica gel column chromatography and semipreparative HPLC to afford five compounds (1-5).

Compound 1. The EIMS showed molecular ion peak at $m / z 176[\mathrm{M}+\mathrm{H}]^{+}$. The UV $(\mathrm{MeOH})$ showed absorbances at $\lambda_{\max }$ 209, 241, 261 and $299 \mathrm{~nm}$ which indicated a 3-acyl indole chromophore ${ }^{11}$. The ${ }^{1} \mathrm{H}$ NMR spectrum (Table 1) revealed an indole structure with 4 proton 
signals at $\delta_{\mathrm{H}} 8.23(1 \mathrm{H}, \mathrm{dd}, J=6.9,1.3 \mathrm{~Hz} ; \mathrm{H}-4), 7.19(1 \mathrm{H}, \mathrm{dt}, J=6.9,1.3 \mathrm{~Hz} ; \mathrm{H}-5), 7.22(1 \mathrm{H}$, dt, $J=6.9,1.3 \mathrm{~Hz} ; \mathrm{H}-6)$ and $7.44(1 \mathrm{H}, \mathrm{dd}, J=6.9,1.3 \mathrm{~Hz} ; \mathrm{H}-7)$ indicative of an ABCD aromatic spin system. In addition, one proton resonated at $\delta_{\mathrm{H}} 8.19(1 \mathrm{H}, \mathrm{s} ; \mathrm{H}-2)$ and the most up-field signal was at $\delta_{\mathrm{H}} 4.73(1 \mathrm{H}, \mathrm{s} ; \mathrm{H}-9)$. The HMBC spectrum (Figure 2), showed correlations which identified 3-hydroxyacetyl-1 $H$-indole (deoxyhyrtiosine A). This compound was previously isolated from the Bermudian sponge Tedania ignis ${ }^{12}$ and its associated bacterium, Micrococcus $s p \cdot{ }^{13}$, but this is the first isolation of $\mathbf{1}$ from the genus Hyrtios.

Compound 2. The EIMS showed a molecular ion peak at $m / z 146[\mathrm{M}+\mathrm{H}]^{+}$. UV $\lambda_{\max }(\mathrm{MeOH})$ : 206, 243, 255, and $298 \mathrm{~nm}$. The ${ }^{1} \mathrm{H}$ NMR (DMSO- $\mathrm{d}_{6}$, Table 1), as in 1 showed four protons resonances for the aromatic ABCD system at $\delta_{\mathrm{H}} 8.07(1 \mathrm{H}, \mathrm{br} . \mathrm{d}, J=7.4 \mathrm{~Hz} ; \mathrm{H}-4), 7.10(1 \mathrm{H}, \mathrm{dt}, J$ $=1.2,7.4 \mathrm{~Hz}$; H-5), $7.30(1 \mathrm{H}, \mathrm{dt}, J=1.3,7.4 \mathrm{~Hz}$; H-6) and $7.60(1 \mathrm{H}$, br.d, $J=7.4 \mathrm{~Hz} ; \mathrm{H}-7)$, in addition to three other proton signals at $\delta_{\mathrm{H}} 8.30(1 \mathrm{H}, \mathrm{s} ; \mathrm{H}-2)$, an aldehydic proton at $\delta_{\mathrm{H}} 9.95(1 \mathrm{H}$, $\mathrm{s} ; \mathrm{H}-8)$ and the most downfield broad singlet at $\delta_{\mathrm{H}} 12.13(1 \mathrm{H}, \mathrm{s} ; \mathrm{H}-1)$. The HMBC (Figure 2), showed correlations which identified an indole-3-carbaldehyde structure. The NMR data were identical to those reported in literature ${ }^{14}$, but this is the first isolation of $\mathbf{2}$ from genus Hyrtios.

Table 1. ${ }^{1} \mathrm{H}$ and ${ }^{13} \mathrm{C}$ NMR data of compounds 1 and 2 (400 and $100 \mathrm{MHz}$ )

\begin{tabular}{ccccc}
\hline \multirow{2}{*}{ Position } & \multicolumn{2}{c}{$\mathbf{2}^{\mathrm{m}}$} & \multicolumn{2}{c}{$\mathbf{3}^{\mathrm{d}}$} \\
\cline { 2 - 5 } & ${ }^{1} \mathrm{H}$ & ${ }^{13} \mathrm{C}$ & ${ }^{1} \mathrm{H}$ & 138.5 \\
2 & $8.19(1 \mathrm{H}, \mathrm{s})$ & 133.6 & $8.30(1 \mathrm{H}, \mathrm{s})$ & 118.1 \\
3 & - & 114.4 & - & 124.1 \\
$3 \mathrm{a}$ & - & 126.3 & - & 120.8 \\
4 & $8.23(1 \mathrm{H}, \mathrm{dd}, J=6.9,1.3 \mathrm{~Hz})$ & 122.0 & $8.07(1 \mathrm{H}, \mathrm{br} . \mathrm{d}, J=7.4 \mathrm{~Hz})$ & 122.1 \\
5 & $7.19(1 \mathrm{H}, \mathrm{dt}, J=6.9,1.3 \mathrm{~Hz})$ & 123.2 & $7.10(1 \mathrm{H}, \mathrm{dt}, J=1.2,7.4 \mathrm{~Hz})$ & 123.4 \\
6 & $7.22(1 \mathrm{H}, \mathrm{dt}, J=6.9,1.3 \mathrm{~Hz})$ & 124.2 & $7.30(1 \mathrm{H}, \mathrm{dt}, J=1.3,7.4 \mathrm{~Hz})$ & 112.4 \\
7 & $7.44(1 \mathrm{H}, \mathrm{dd}, J=6.9,1.3 \mathrm{~Hz})$ & 113.0 & $7.60(1 \mathrm{H}, \mathrm{br} . \mathrm{d}, J=7.4 \mathrm{~Hz})$ & 137.1 \\
$7 \mathrm{a}$ & - & 138.1 & - & 185 \\
8 & - & 196.2 & $9.95(1 \mathrm{H}, \mathrm{s})$ & - \\
9 & $4.73(2 \mathrm{H}, \mathrm{s})$ & 66.3 & - &
\end{tabular}

m: $\mathrm{CD}_{3}$ OD. ${ }^{\mathrm{d}}:$ DMSO-d.

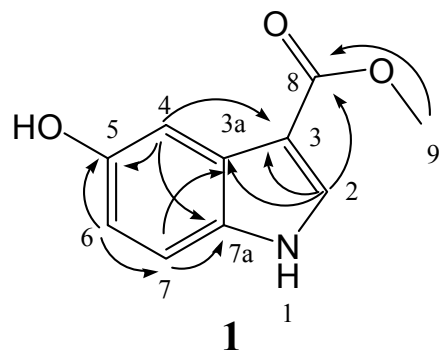

Figure 2. HMBC correlations of $\mathbf{1}$ and 2.

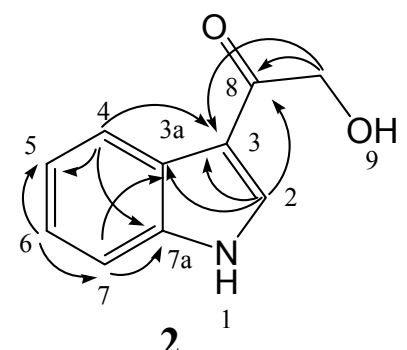

2

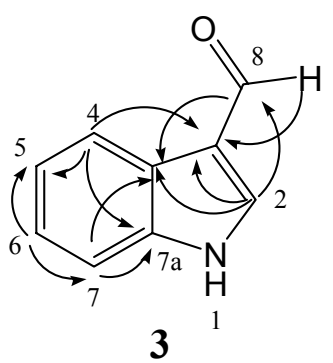

3 
Compound 3. Isolated as a translucent needle crystals. EIMS showed molecular ion peak of $m / z 191[\mathrm{M}]^{+}$, the HREIMS revealed its formula to be $\mathrm{C}_{10} \mathrm{H}_{9} \mathrm{NO}_{3}$. The ${ }^{1} \mathrm{H}$ and ${ }^{13} \mathrm{C} \mathrm{NMR}$ data were consistent with those of 5-hydroxy-1H-indole-3-carboxylic acid methyl ester; this compound was previously isolated from the same sponge. ${ }^{15}$

Compound 4. Isolated as a brownish translucent amorphous powder with a characteristic odour and had a molecular formula of $\mathrm{C}_{9} \mathrm{H}_{7} \mathrm{NO}_{2}$ based on the results of FABMS, ${ }^{1} \mathrm{H}$ and ${ }^{13} \mathrm{C}$ NMR data. The ${ }^{1} \mathrm{H}$ and ${ }^{13} \mathrm{C}$ NMR spectral data of 4 were consistent with those of 5-hydroxy-1Hindol-3-carbaldehyde which was previously isolated from $H$. erectus ${ }^{11}$ and from Dragmacidon sp. ${ }^{16}$

Compound 5. Isolated as a brownish translucent amorphous powder, with slightly offensive characteristic odour and had a molecular formula of $\mathrm{C}_{10} \mathrm{H}_{9} \mathrm{NO}_{3}$ based on the results of FABMS, ${ }^{1} \mathrm{H}$ and ${ }^{13} \mathrm{C}$ NMR data. The ${ }^{1} \mathrm{H}$ and ${ }^{13} \mathrm{C}$ NMR spectral data of 5 were consistent with those of hyrtiosine A that was previously isolated from the same sponge ${ }^{11}$ and from Dragmacidon sp. ${ }^{16}$

Compound 6. Isolated as a colourless amorphous solid and had a molecular formula of $\mathrm{C}_{25} \mathrm{H}_{38} \mathrm{O}_{4}$ as established from its FABMS and ${ }^{13} \mathrm{C}$ NMR data. The structural assignments of 6 were based on an accurate study of the 1D and 2D (COSY, HMQC, HMBC) NMR spectra. The ${ }^{1} \mathrm{H}$ and ${ }^{13} \mathrm{C}$ NMR spectral data of 6 were consistent with the data for 16-hydroxyscalarolide, which was previously reported from the Okinawan sponge H. erectus ${ }^{2}$.

Compound 7. Isolated as a brownish white amorphous solid and had a molecular formula of $\mathrm{C}_{25} \mathrm{H}_{38} \mathrm{O}_{3}$, as established from its FABMS and ${ }^{13} \mathrm{C}$ NMR data. The structural assignments of 7 were based on an accurate study of the 1D and 2D (COSY, HMQC, HMBC) NMR spectra. The ${ }^{1} \mathrm{H}$ and ${ }^{13} \mathrm{C}$ NMR spectral data of 7 were consistent with the data for scalarolide, which was previously reported from the sponge Spongia idia ${ }^{17}$.

Compound 8. Isolated as a white amorphous solid and had a molecular formula of $\mathrm{C}_{25} \mathrm{H}_{38} \mathrm{O}_{4}$ as established from its FABMS and ${ }^{13} \mathrm{C}$ NMR data. The structural assignments of 8 were based on an accurate study of the 1D and 2D (COSY, HMQC, HMBC) NMR spectra. The ${ }^{1} \mathrm{H}$ and ${ }^{13} \mathrm{C}$ NMR spectral data of $\mathbf{8}$ were consistent with the data for 12 -episcalarin ${ }^{18,19}$ and suggested that $\mathbf{8}$ was a deacetyl derivative of 12-episcalarin and identical with the previously published 12-Odeacetyl-12-epi-scalarin which isolated from Spongia $s p .^{18}$

Compound 9. Isolated as white needle crystals and had a molecular formula of $\mathrm{C}_{27} \mathrm{H}_{44} \mathrm{O}_{3}$ as established from its FABMS and ${ }^{13} \mathrm{C}$ NMR data. The structural assignments of 9 were based on an accurate study of the 1D and 2D (COSY, HMQC, HMBC) NMR spectra. The ${ }^{1} \mathrm{H}$ and ${ }^{13} \mathrm{C}$ NMR spectral data of $5 \alpha, 8 \alpha$-epidioxy-cholesta-6-en-3 $\beta$-ol. ${ }^{20}$

On testing the cytotoxic activities of the isolated compounds, it was found that compound 6 (16 hydroxyscalarolide) showed 40.5 and $55.3 \%$ growth inhibition activity against L5178Y cells at concentrations $3.0 \mu \mathrm{g}$ and $10.0 \mu \mathrm{g}$ respectively, compound 3 (5-hydroxy- $1 H$-indole-3carboxylic acid methyl ester) showed $36 \%$ cytotoxic activity at concentration $10.0 \mu \mathrm{g} / \mathrm{ml}$, while compound 2 (indole-3-carbaldehyde) showed 53\% cytotoxic activity at concentration 10.0 $\mu \mathrm{g} / \mathrm{ml}$. On testing the antimicrobial activity it was found that compounds $\mathbf{1}$ (deoxyhyrtiosine), $\mathbf{5}$ 
(5-hydroxy-1H-indole-3-carbaldehyde) and 6 (16-hydroxyscalarolide) have mild antimicrobial activities against Bacillus subtilis and Saccharomyces cerevisiae.

\section{Experimental Section}

General Procedures. ${ }^{1} \mathrm{H}\left(1 \mathrm{D}, 2 \mathrm{D}\right.$ COSY) and ${ }^{13} \mathrm{C}(1 \mathrm{D}, 2 \mathrm{D}$ HMBC) NMR spectra were recorded on a Bruker ARX 400 NMR spectrometer. Mass spectra recorded on Finningan MAT TSQ-7000 mass spectrometer, while HREIMS were obtained on a Finningan MAT 900 mass spectrometer. UV spectra were measured in methanol on a Perkin-Elmer UV/Vis lambda spectrophotometer. Solvents were distilled prior to use, and spectral grade solvents were used for spectroscopic measurements. TLC was performed on TLC plates pre-coated with silica gel $\mathrm{F}_{254}$ (Merck, Darmstadt, Germany). Semipreparative HPLC was performed on HPLC system (Merck, Darmstadt, Germany) coupled with UV detector L7400 (UV detection at $280 \mathrm{~nm}$ ), the separation column $(8 \times 250 \mathrm{~mm})$ pre-packed with Eurosphere $\mathrm{C}_{18}$ (Knauer, Berlin, Germany). The compounds were eluted with solvent system of $\mathrm{MeOH} / \mathrm{H}_{2} \mathrm{O}$ containing $1 \%$ TFA for improved separation, at a flow rate of $5 \mathrm{ml} / \mathrm{min}$.

Animal material. The $H$. erectus was collected at a depth of 30 feet $5 \mathrm{~km}$ to the north of Hurghada, Egypt in March 2003 and was kept in ethanol immediately after collection. A voucher specimen has been deposited in the Zoological Museum Amsterdam under registration number ZMA POR18348.

Extraction and isolation. The freeze-dried sponges were extracted exhaustively with methanol then with acetone. The resulting crude extracts were first partitioned between $\mathrm{H}_{2} \mathrm{O}$ and $\mathrm{CH}_{2} \mathrm{Cl}_{2}$ followed by evaporation of the aqueous layer and dissolving the residue in methanol. The $\mathrm{CH}_{2} \mathrm{Cl}_{2}$ soluble material of $H$. erectus (1.2 g) was subjected to vacuum-liquid chromatography on silica gel, using gradient elution with $\mathrm{CH}_{2} \mathrm{Cl}_{2}-\mathrm{MeOH}$. Eleven fractions were obtained, fractions 60:40, 50:50, 40:60 and 30:70 $\left(\mathrm{CH}_{2} \mathrm{Cl}_{2}-\mathrm{MeOH}\right)$ were further subjected to silica gel column chromatography to yield compounds $6(3.5 \mathrm{mg}), 7(2.3 \mathrm{mg}), 8(4 \mathrm{mg})$ and $9(5 \mathrm{mg})$. The methanol soluble residue $(0.92 \mathrm{~g})$ was subjected to vacuum-liquid chromatography on silica gel, using gradient elution with $\mathrm{CH}_{2} \mathrm{Cl}_{2}-\mathrm{MeOH}$. Ten fractions were obtained, fractions 50:50, 40:60 and 30:70 $\left(\mathrm{CH}_{2} \mathrm{Cl}_{2}-\mathrm{MeOH}\right)$ were further subjected to silica gel column chromatography followed by semipreparative HPLC as a final purification step to yield compounds 1 (2.5 mg), 2 (2.5 mg), 3 (3 mg), 4 (2 mg) and 5 (5 mg).

Cytotoxicity assay. The cytotoxicity was evaluated by the $\left[{ }^{3} \mathrm{H}\right]$ Thymidine assay ${ }^{21}$ against mouse lymphoma (L5178Y), rat brain cancer cells (PC12) and human cervix cancer cells (HELA). All cells were mycoplasma-free and cultures were propagated under standardised conditions. $^{22}$ 
Agar plate diffusion assay. ${ }^{23}$ Susceptibility discs $(5.5 \mathrm{~mm})$ were impregnated with 50 and 100 $\mu \mathrm{g}$ of the pure isolated compounds, dried and placed on agar plates with the test organisms: $B$. subtilis 168, S. aureus ATCC 25923, E. coli ATCC 25922 and Saccharomyces cereviisae. The plates were incubated at $37{ }^{\circ} \mathrm{C}$ and checked for inhibition zones after $24 \mathrm{~h}$ for bacteria and after $48 \mathrm{hrs}$ for fungi.

Deoxyhyrtiosine A (1). Colourless amorphous powder. EIMS $m / z(\%): 176(68)[\mathrm{M}+\mathrm{H}]^{+}$.

Indole-3-carbaldehyde (2). Yellowish white amorphous powder, with slightly offensive characteristic odour. EIMS $m / z(\%): 146(72)[\mathrm{M}+\mathrm{H}]^{+}$.

5-hydroxy-1 $H$-indole-3-carboxylic acid methyl ester (3). UV $\lambda_{\max }(\mathrm{MeOH}): 213,241$ and 286 nm. EI-MS m/z (\%): 191(74), 160 (100), 132 (26), 91 (13).

5-Hydroxy-1H-indol-3-carbaldehyde (4). UV $\lambda_{\max }(\mathrm{MeOH}): 211,252,271$ and $302 \mathrm{~nm}$. EIMS $m / z(\%): 162(38)[\mathrm{M}+\mathrm{H}]^{+}, 134(100)$.

Hyrtiosine A (5). UV $\lambda_{\max }(\mathrm{MeOH}) 213,251,271$ and $302 \mathrm{~nm}$.

EIMS $m / z(\%): 192(66)[\mathrm{M}+1]^{+}$.

16-Hydroxyscalarolide (6). UV $\lambda_{\max }(\mathrm{MeOH}) 216 \mathrm{~nm}$.

FABMS m/z (\%): 425 (52) [M+ H] $]^{+}, 403$ (68) [M+ H], 385 (54), 367 (38), 329 (45), 307 (100), 289 (82), 273 (31), 243 (27), 211 (25).

Scalarolide (7). UV $\lambda_{\max }(\mathrm{MeOH}) 220 \mathrm{~nm}$.

FABMS m/z (\%): 409 (63) [M+ Na], 387 (89) [M+ H] $]^{+}, 369$ (100), 329 (35), 307(58), 289 (59), 257 (48), 231 (40), 205 (39).

12-O-deacetyl-12-epi-scalarin (8). UV $\lambda_{\max }(\mathrm{MeOH}) 221 \mathrm{~nm}$.

FABMS $m / z$ (\%): 402 (12) [M] $]^{+}, 384$ (22), 356(28), 275(35), 191(100), 149(40), 123(60).

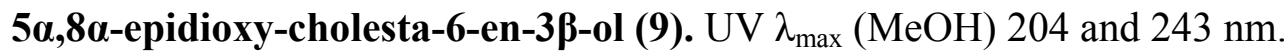

FABMS m/z (\%): 439 (39) [M+ Na] , 384 (100), 365 (72), 352 (28), 329 (19), 307(42), 299 (38), 269 (14).

\section{Acknowledgements}

The authors are grateful to W. M. Van Soest, Head Section Invertebrates, Zoological Meuseum, University of Amsterdam, Amsterdam, Netherlands, for identification of the sponge and Prof. Dr. W. E. G. Müller, Institut of Physiological Chemistry, Johannes Gutenberg-Univerität, Mainz, Germany, for the cytotoxicity assay.

\section{References}

1. Kobayashi, M.; Okamoto, T.; Hayashi, K.; Yokoyama, N.; Sasaki, T.; Kitagawa, I. Chem. Pharm. Bull. 1994, 42, 265.

2. Miyaoka, H.; Nishijima, S.; Mitome, H.; Yamada, Y. J. Nat. Prod. 2000, 63, 1369. 
3. Pettit, G. R.; Cichacz, Z. A.; Tan, R.; Herald, D. L.; Melody, N.; Hoard, M. S.; Doubek, D. L.; Hooper, J. N. A. Collect. Czech. Chem. Commun. 1998, 63, 1671.

4. Youssef, D. T. A.; Shaala, L. A.; Emara, S. J. Nat. Prod. 2005, 68, 1782.

5. Youssef, D. T.; Yamaki, R. K.; Kelly, M.; Scheuer, P. J. J. Nat. Prod. 2002, 65, 2.

6. Pettit, G. R.; Cichacz, Z. A.; Gao, F.; Herald, C. L.; Boyd, M. R.; Schmidt, J. M.; Hooper, J. N. A. J. Org. Chem. 1993, 58, 1302.

7. Pettit, G. R.; Cichacz, Z. A.; Herald, C. L.; Gao, F.; Boyd, M. R.; Schmidt, J. M.; Hamel, J.; Bai, R. J. Chem. Soc., Chem. Commun. 1994, 1605.

8. Pettit, G. R.; Cichacz, Z. A.; Tan, R.; Hoard, M. S.; Melody, N.; Pettit, R. K. J. Nat. Prod. 1998, 61, 13.

9. Pettit, G. R.; Tan, R.; Melody, N.; Cichacz, Z. A.; Herald, D. L.; Hoard, M. S.; Pettit, R. K.; Chapuis, J. C. Bioorg. Chem. Lett. 1998, 8, 2093.

10. Pettit, G. R.; Tan, R.; Cichacz, Z. A. J. Nat. Prod. 2005, 68, 1253.

11. Kobayashi, J.; Murayama, T.; Ishibashi, M.; Kosuge, S.; Takamatsu, M.; Ohizumi, Y.; Kobayashi, H.; Ohta, T.; Nozoe, S.; Sasaki, T. Tetrahedron Lett. 1990, 46, 7699.

12. Dillman, R. L.; Cardellina, J. H. J. Nat. Prod. 1991, 54, 1056.

13. Stierle, A A. Investigation of Biologically Active Metabolites from Symbiotic Microorganisms, Ph.D. Dissertation, Montana State University, Bozeman, 1988.

14. Hiort, J., Neue Naturstoffe aus Schwamm-assoziierten Pilzen des mittelmeeres-Isolierung strukturaufklärung und biologischen aktivität, Heinrich-Heine Universität, 2002.

15. Sauleau, P.; Martin, M.; Huu Dau, M. T.; Youssef, D.; Bourguet-Kondracki, M. J. Nat. Prod. 2006, 69, 1676.

16. Pedpradab, S.; Ederada, R.; Ebel, R.; Wray, V.; Proksch, P. J. Nat. Prod. 2004, 67, 2113.

17. Walker, R. P.; Thompson, J. E.; Faulkner, D. J. J. Org. Chem. 1980, 45, 4976-4979.

18. Tsukamoto, S.; Miura, S.; van Soest, R. W. M.; Ohta, T. J. Nat Prod. 2003, 66, 438.

19. Cimino, G.; De Stefano, S.; Minale, L.; Trivellone, E. J. Chem. Soc., Perkin Trans. 1977, 1587.

20. Gauvin, A.; Smadja, J.; Aknin, M.; Faure, R.; Gaydou, E-M. Can J. Chem. 2000, 78, 986.

21. Carmichael, J.; DeGraff, W. G.; Gazdar, A. F.; Minna, J. D.; Mitchell, J. B. Cancer Res. 1987, 47, 943.

22. Kreuter, M. H.; Robitzki, A.; Chang, S.; Steffen, R.; Michaelis, M.; Kljajic, Z.; Bachmann, M.; Schröder, H. C.; Müller, W. E. G. Comp. Biochem. Physiol. 1992, 101C, 183.

23. Elkhayat, E.; Edrada, R.; Ebel, R.; Wray, V.; Van Soest, R.; Wiryowidagdo, S.; Mohammed, H. M.; Muller, W. E. G.; Proksch, P. J. Nat. Prod. 2004, 67, 1809. 